Original Paper http://ajol.info/index.php/ijbcs http://indexmedicus.afro.who.int

\title{
Some physiochemical changes associated with type 2 diabetes mellitus in Benin City, Nigeria
}

\section{F.A. EHIAGHE}

Department of Hematology, College of Health Sciences, Igbinedion University, Okada, Nigeria. Lahor Research and Medical Centre, 121 Old Benin-Agbor Road, Benin City, Nigeria. Department of Medical Laboratory sciences, Nnamdi Azikiwe University, Awka, Nigeria. E-mail :fredleo2547@yahoo.com

\begin{abstract}
The present study was designed to determine the level of malondialdehyde (MDA) concentration, serum $\mathrm{c}$ reactive protein $(\mathrm{CRP})$ and $\mathrm{CD}^{+} \mathrm{T}$ cells in type 2 diabetes mellitus in a view to assessing the complications associated with the non specific activation of $\mathrm{CD} 4^{+} \mathrm{T}$ cells. A total of 80 subjects aged between 18 and 50 years gave their consent to participate in the study. They consist of 40 known type 2 diabetes mellitus and 40 aged matched apparently healthy control subjects on routine checkup. Malondialdehyde concentration was determined by spectrophotometric method. Serum c reactive protein was determined by enzyme-linked immunosorbent assay method. $\mathrm{CD}^{+} \mathrm{T}$ cells were estimated using Partec cyflow counter. There was a significant increase in MDA concentration, CRP and $\mathrm{CD} 4^{+} \mathrm{T}$ cells in type 2 diabetes mellitus subjects when compared with the aged matched control group $(\mathrm{P}<0.05)$. Type 2 diabetes mellitus causes an increased production of free radicals which is possibly linked to the complications associated with non specific activation of $\mathrm{CD} 4^{+} \mathrm{T}$ cells.

(C) 2015 International Formulae Group. All rights reserved.
\end{abstract}

Keywords: Free radicals, CD4+ T cells, diabetes mellitus, cytokines, c reactive protein, malondialdehyde.

\section{INTRODUCTION}

The prevalence of diabetes mellitus is increasing rapidly worldwide and the World Health Organization (2003) has predicted that by 2030 the number of adults with diabetes would have almost doubled worldwide, from 177 million in 2000 to 370 million (Rowley and Bezold, 2012). Diabetes mellitus is a complex syndrome characterized by absolute or relative insulin deficiency leading to hyperglycemia and an altered metabolism of glucose, fat, and protein (Remuzzi et al.,
2002; Caramori and Mauer, 2003; Wolf and Ritz, 2003).

Since more than $90 \%$ of the global cases of diabetes mellitus are type 2 , it is evident that the epidemic is mainly due to the escalation of the causes of type 2 diabetes mellitus. According to the current definition, two fasting glucose measurement above 126 $\mathrm{mg} / \mathrm{dl}(7.0 \mathrm{mmol} / \mathrm{L})$ are considered diagnostic for diabetes mellitus or Glycated hemoglobin (HbA1C) above 6.5\% (Sayalah et al., 2001; WHO, 2003; Motala, 2008; Chinenye et al., 
2008). Experimental evidence demonstrated that $\mathrm{c}$ reactive proteins is a sensitive physiological biomarker of sub clinical systemic inflammation which is associated with hyperglycemia, insulin resistance and overt type 2 diabetes mellitus ( $\mathrm{Su}$ et al., 2010).

Lipid peroxidation is a well established mechanism of cellular injury and is used as an indicator of oxidative stress in cells and tissues. The measurement of malondialdehyde is widely used as an indicator of lipid peroxidation and increased level of the peroxidation products have been associated with a variety of acute and chronic pathophysiological processes including type 2 diabetes mellitus (Killic et al., 2003). Recent research suggests that patients with elevated basal level of CRP are at an increased risk of diabetes mellitus, hypertension and cardiovascular disease (Clearfield, 2005). However; could the elevation of MDA and CRP play a major role in diabetogenesis? This question, if explored, may open new doors in the understanding of the complication associated with type 2 diabetes mellitus. Thus, the present study was designed to determine the level of MDA, CRP and $\mathrm{CD} 4^{+} \mathrm{T}$ cells in type 2 diabetes mellitus in a view to assessing the complications associated with the non specific activation of $\mathrm{CD} 4^{+} \mathrm{T}$ cells.

\section{MATERIALS AND METHODS Subjects}

A total of 80 subjects aged between 18 and 60 years gave their consent to participate in the study. They consist of 40 known type 2 diabetes mellitus and 40 aged matched apparently healthy control subjects on routine checkup. They were confirmed to be diabetics and non diabetics respectively using the glucose oxidase method as previously described by Ehiaghe et al. (2013).

\section{Inclusion criteria}

Both males and females were included in the study.

\section{Exclusion criteria}

Pregnant women and those diagnosed with other systemic diseases were excluded from this study.

\section{Physiological measurements}

The subjects resting systolic blood pressure and diastolic blood were measured from the right arm as described by Musa et al. (2002). Using an automated digital electronic BP monitor (Omron digital BP monitor, Model 11 EM 403c; Tokyo Japan.

\section{Collection of blood samples}

Nine milliliters of fasting venous blood was collected from the medial cubital vein using vacutainer and needle from each of the subjects and shared equally into ethylene diamine tetra acetic acid, sodium fluoride potassium oxalate and plain containers.

\section{Determination of blood glucose level}

Glucose oxidase method was used in the determination of blood glucose as previously described by Ehiaghe et al. (2013). In brief, $10 \mu 1$ of the standard or test samples was added to $1000 \mu \mathrm{l}$ of glucose reagent 1 , mixed and incubated for 25 minutes at 20 ${ }^{0} \mathrm{C}$.The absorbance of the standard and test samples was measured against the reagent blank within 60 minutes at a wavelength of $540 \mathrm{~nm}$ using a spectrophotometer.

\section{Determination of serum $\mathrm{c}$ reactive protein \\ Enzyme-linked immunosorbent assay} (ELISA) was used in the determination of the level of $\mathrm{c}$ reactive protein in the serum. The assay employs an antibody specific for $\mathrm{c}$ reactive protein coated on a 96 well plate. Briefly, $100 \mu \mathrm{l}$ of the assay diluents was added to each well. $50 \mu 1$ of standard or 
sample(s) was added per well and mixture was incubated for 2 hours. The solution was discarded and microplates washed four times with $300 \mu \mathrm{l}$ of $1 \mathrm{X}$ wash solution. $200 \mu \mathrm{l}$ reactive protein conjugate was added to the standard or sample(s) and covered with a sealing tape. It was incubated at room temperature for 2 hours. The solution was discarded and microplates washed four times with $300 \mu \mathrm{l}$ of $1 \mathrm{X}$ wash solution. $200 \mu \mathrm{l}$ of tetraethyl benzidine substrate was added to each well and incubated for 30 minutes at room temperature in the dark with gentle shaking. $50 \mu \mathrm{l}$ of stop solution was added to each microplate. The intensity of the color developed was measured at $450 \mathrm{~nm}$ wavelength using stat fax® 4700 micro strip reader as previously described by Ehiaghe et al. (2013).

\section{$\mathrm{CD4}^{+} \mathrm{T}$ cell count estimation}

$\mathrm{CD} 4^{+} \mathrm{T}$ cell count was estimated using Partec cyflow counter as described by Partec cyflow counter (2006).

\section{Malondialdehyde estimation}

Reagent 1: (Trichloroacetic acid 17.5\%);

Reagent -2 :( Trichloroacetic acid 70\%);

Reagent - 3: (Thiobarbituric acid 0.6\%) TBA

Malondialdehyde in the serum was determined as conjugated with TBA. The reaction was performed in $18 \times 150 \mathrm{~mm}$ Pyrex test tube labeled as: test and blank, into which $1 \mathrm{ml}$ each of reagents 1,2 , and 3 was added into them respectively. $1 \mathrm{ml}$ of the serum was added to the test tube labeled test while 1 $\mathrm{ml}$ of distilled water was added to the test tube labeled blank. The tubes were mixed well and incubated in boiling bath for 15 minutes, allowed to cool. The tubes let to stand at room temperature for 20 minutes. Then the tubes centrifuged at $2000 \mathrm{rpm}$ for 15 minutes. The supernatant layer was read at $534 \mathrm{~nm}$ with a spectrophotometer. The concentration of MDA
( $\mu \mathrm{mol} / \mathrm{L}$ ) was calculated by using the following formula: Concentration of the test $=$ Abs (test) Abs (blank) / 1.56 x 1000000 as previously described by Mossa et al. (2009).

\section{Statistical analysis}

All numerical variables were expressed in mean $( \pm \mathrm{SD})$ and analyzed using one way analysis of variance (ANOVA).Using SPSS version 20.0. Significant level was considered at $\mathrm{P}<0.05$.

\section{Ethics}

Ethical approval was obtained from the ethical committee of the Lahor Research Laboratories and Medical centre in Benin City, Edo State, Nigeria with reference number LRL/008/014.

\section{RESULTS}

Our findings revealed that there was no significant difference in SBP, DBP, Glucose, $\mathrm{CRP}, \mathrm{CD} 4^{+} \mathrm{T}$ cells and MDA concentration of the males type 2 diabetes mellitus when compared with females type 2 diabetes mellitus ( $\mathrm{P}>0.05)$. There was also no significant difference with males control group when compared with females control group $(\mathrm{P}>0.05)$, (Table 1).

There was a significant increase in SBP, DBP, Glucose, CRP, CD $4^{+} \mathrm{T}$ cells and MDA concentration of type 2 diabetes mellitus when compared with the aged matched control group ( $\mathrm{P}<0.05)$, (Table 2$)$. Our finding also revealed a significant increase in SBP, DBP, Glucose, CRP, CD4 ${ }^{+} \mathrm{T}$ cells and MDA concentration of the male type 2 diabetes mellitus when compared with the males control group ( $\mathrm{P}<0.05)$, (Table 3 ). A significant increase in SBP, DBP, Glucose, $\mathrm{CRP}, \mathrm{CD}^{+} \mathrm{T}$ cells and MDA concentration of the females type 2 diabetes mellitus compared with the females control group $(\mathrm{P}<0.05)$, (Table 3). 
Table 1: Comparison of mean $( \pm \mathrm{SD})$ SBP $(\mathrm{mm} . \mathrm{Hg})$, DBP $(\mathrm{mm} . \mathrm{Hg})$, Glucose $(\mathrm{mg} / \mathrm{dl})$, CRP (ng/l), $\mathrm{CD}^{+} \mathrm{T}$ cell count $(\mathrm{cells} / \mu \mathrm{l})$, and MDA $(\mu \mathrm{mol} / \mathrm{L})$ between type 2 diabetes mellitus (DM) groups and the control groups respectively.

\begin{tabular}{lcccccc}
\hline Parameter & SBP & DBP & Glucose & CRP & $\begin{array}{c}\text { CD4 }^{+} \text {T } \\
\text { cell count }\end{array}$ & MDA \\
\hline Male type 2 DM(n=22) & $140 \pm 10.4$ & $83 \pm 7.1$ & $162 \pm 43$ & $144 \pm 46$ & $660 \pm 69$ & $3.1 \pm 0.29$ \\
Female type 2 DM $(\mathrm{n}=18)$ & $140 \pm 8.8$ & $83 \pm 7.5$ & $151 \pm 41$ & $139 \pm 52$ & $661 \pm 80$ & $2.9 \pm 0.34$ \\
P- value & $>0.05$ & $>0.05$ & $>0.05$ & $>0.05$ & $>0.05$ & $>0.05$ \\
\hline Male control group $(\mathrm{n}=22)$ & $116 \pm 3.5$ & $74 \pm 4.2$ & $89 \pm 11$ & $1.5 \pm 1.7$ & $504 \pm 74$ & $1.56 \pm 0.4$ \\
Female control group $(\mathrm{n}=18)$ & $117 \pm 3.3$ & $73 \pm 4.6$ & $88 \pm 14.7$ & $1.8 \pm 2.3$ & $508 \pm 60$ & $1.49 \pm 0.35$ \\
P-value & $>0.05$ & $>0.05$ & $>0.05$ & $>0.05$ & $>0.05$ & $>0.05$ \\
\hline P $<0.05$ was considered significant. & & & & & &
\end{tabular}

Table 2: Comparison of mean $( \pm \mathrm{SD}) \mathrm{SBP}(\mathrm{mm} . \mathrm{Hg})$, DBP (mm.Hg), Glucose (mg/dl), CRP (ng/l), $\mathrm{CD}^{+} \mathrm{T}$ cell count $($ cells $/ \mu \mathrm{l})$, and MDA $(\mu \mathrm{mol} / \mathrm{L})$ of the type $2 \mathrm{DM}$ with the control groups irrespective of gender.

\begin{tabular}{lcccccc}
\hline Parameters & SBP & DBP & Glucose & CRP & $\begin{array}{c}\text { CD4 }^{+} \text {T cell } \\
\text { count }\end{array}$ & MDA \\
\hline Type 2 DM $(\mathrm{n}=40)$ & $140 \pm 1.51$ & $83 \pm 1.13$ & $160 \pm 6.7$ & $141 \pm 7.6$ & $661 \pm 75$ & $3.0 \pm 0.05$ \\
Control group $(\mathrm{n}=40)$ & $116 \pm 0.54$ & $73.4 \pm 0.69$ & $88.5 \pm 2.02$ & $1.7 \pm 0.3$ & $506 \pm 67$ & $1.53 \pm 0.06$ \\
P- value & $<0.05$ & $<0.05$ & $<0.05$ & $<0.05$ & $<0.05$ & $<0.05$ \\
\hline P $<0.05$ was considered significant & & & & &
\end{tabular}

Table 3: Comparison of mean $( \pm \mathrm{SD}) \mathrm{SBP}(\mathrm{mm} . \mathrm{Hg})$, DBP (mm.Hg), Glucose (mg/dl), CRP (ng/l), $\mathrm{CD}^{+} \mathrm{T}$ cell count $($ cells $/ \mu \mathrm{l})$, and MDA $(\mu \mathrm{mol} / \mathrm{L})$ of type $2 \mathrm{DM}$ and control groups with gender biased.

\begin{tabular}{|c|c|c|c|c|c|c|}
\hline Parameter & SBP & DBP & Glucose & CRP & $\begin{array}{l}\text { CD4 }^{+} \text {T cell } \\
\text { count }\end{array}$ & MDA \\
\hline $\begin{array}{l}\text { Male type } 2 \\
\operatorname{DM}(n=22)\end{array}$ & $140 \pm 10.4$ & $83 \pm 7.1$ & $162 \pm 43$ & $144 \pm 46$ & $660 \pm 69$ & $3.1 \pm 0.29$ \\
\hline $\begin{array}{l}\text { Male control } \\
\text { group }(n=22)\end{array}$ & $116 \pm 3.5$ & $74 \pm 4.2$ & $89 \pm 11$ & $1.5 \pm 1.7$ & $504 \pm 74$ & $1.56 \pm 0.4$ \\
\hline $\mathrm{P}$ - value & $<0.05$ & $<0.05$ & $<0.05$ & $<0.05$ & $<0.05$ & $<0.05$ \\
\hline $\begin{array}{l}\text { Female type } 2 \\
D M(n=18)\end{array}$ & $140 \pm 8.8$ & $83 \pm 7.5$ & $151 \pm 41$ & $139 \pm 52$ & $661 \pm 80$ & $2.9 \pm 0.34$ \\
\hline $\begin{array}{l}\text { Female control } \\
\text { group }(n=18)\end{array}$ & $117 \pm 3.3$ & $73 \pm 4.6$ & $88 \pm 14.7$ & $1.8 \pm 2.3$ & $508 \pm 60$ & $1.49 \pm 0.35$ \\
\hline P-value & $<0.05$ & $<0.05$ & $<0.05$ & $<0.05$ & $<0.05$ & $<0.05$ \\
\hline
\end{tabular}




\section{DISCUSSION}

The prevalence of diabetes mellitus is increasing rapidly worldwide and World Health Organization (2003) has predicted that by 2030 the number of adults with diabetes would have almost doubled worldwide. There is scarcity of published report on the physiochemical changes associated with type 2 diabetes mellitus in Benin City, hence these study. A significant increase in malondialdehyde concentration seen in both males and females type 2 diabetes mellitus subjects as compared with the control groups (Tables 2 and 3). This could be attributed to the increased production of free radical occasioned by the auto-oxidation of glucose and lipid peroxidation. This is in accordance with these findings. The increased level of lipid peroxides can cause oxidative injury to blood cells, cross-linking of membrane lipids and protein, increasing of cell ageing, imbalance of prostacyclin/prostaglandin and vasoconstriction (Jain et al., 1996). Our findings also revealed that there was no significant difference in SBP, DBP, Glucose, $\mathrm{CRP}, \mathrm{CD} 4^{+} \mathrm{T}$ cells and MDA concentration of the males type 2 diabetes mellitus when compared with females type 2 diabetes mellitus (Table 1). This may be attributed to the common outcome of diabetogenesis regardless of gender affiliation. The aberrant production of inflammatory cytokines and chemokines as well as differential activation of $\mathrm{T}$ helper cells and monocytes is the underlying immunopathological mechanism of type 2 diabetes mellitus patients (Lim et al., 2009).

The significant increase in $\mathrm{CD}^{+} \mathrm{T}$ cells, CRP, SBP and DBP of the diabetics groups (Tables 2 and 3 ) when compared with the non diabetics groups (Table 1 and 2). This could be linked to the non specific activation of the $\mathrm{T}$ helper cells by free radical generated from the auto-oxidation of glucose, lipid, protein peroxidation and a possible destruction of endothelial cells of the renal and cardiovascular system by the non specific mediator released by the activated $\mathrm{T}$ cells. This is in accordance with the findings. Activated $\mathrm{T}$ cells can cause injury directly through cytotoxic effects and indirectly by recruiting and activating macrophages. Proinflammatory cytokines secreted by $\mathrm{T}$ $\left(\mathrm{CD}^{+}, \mathrm{CD}^{+}\right)$cells could activate neighboring macrophages directly or by stimulating mesangial cell production of colony stimulating factor-1 and MCP-1 indirectly. Once macrophages have activated, they can release nitric oxide, reactive oxygen species, IL-1, TNF- $\alpha$, complement factors, and metalloproteinase, all of which promote renal injury (Wang and Harris, 2011). An increased body of evidence indicates that immigrated blood leukocytes might considerably alter the phenotype of endothelial cells and increase inflammation of the vascular bed (Endemann and Schiffrin, 2004). Endothelial dysfunction is associated with most forms of cardiovascular disease, such as coronary artery disease, chronic renal failure and Diabetes mellitus (Stehouwer, 2004). The interaction of renal tissue macrophages and $\mathrm{T}$ cells produces various reactive oxygen species, proinflammatory cytokines, metalloproteinase, and growth factor, which modulate the local response and increase inflammation within the cells (Yamagishi et al., 2007). Experimental evidence demonstrated that $\mathrm{c}$ reactive proteins is a sensitive physiological biomarker of sub clinical systemic inflammation which is associated with hyperglycemia, insulin resistance and overt type 2 diabetes mellitus (Su et al., 2010).

\section{Conclusion}

It was observed that type 2 diabetes mellitus causes an increased production of free radical which is possibly linked to the non specific activation of $\mathrm{CD} 4^{+} \mathrm{T}$ cells. The 
molecular mechanism underlying the complications associated with the non specific activation of $\mathrm{CD}^{+} \mathrm{T}$ Cells needs further investigation.

\section{REFERENCES}

Caramori ML, Mauer M. 2003. Diabetes and nephropathy. Current Opinion in Nephrology and Hypertension, 12: 273-282.

Chinenye S, Uchenna DI, Unachukwu CN, Ogbera AO, Ojule AC. 2008. The pattern of diabetes mellitus in Rivers State, Nigeria. Nigeria Endocrine Practice, 2: 87-93.

Cleafield MB. 2005. C reactive protein: A new assessment tool for cardiovascular disease. The Journal of the American Osteopathic Association, 105: 409-416.

Ehiaghe AF, Agbonlahor DE, Tatfeng YM, Onikepe F, Oviasogie FE, Ehiaghe IJ. 2013. Serum c reactive protein level in type 2 diabetes mellitus patients attending diabetics clinic in Benin City,Nigeria. Journal of Diabetes mellitus, 31: 68-171.

Endemann DH, Schiffrin EL. 2004. Endothelial dysfunction. Journal of the American Society of Nephrology, 15: 1983-1992.

Jain SK, McVie R, Jaramillo JI, Palmer M, Smith T, Meachurr ZD. 1996. The effect of modest vitamin $\mathrm{E}$ supplementation or lipid peroxidation products and other cardiovascular risk factors in diabetic patients. Lipids, 31: 87-90.

Killic E, Suleyman Y, Recep S, Hatice O. 2003. Serum malondialdehyde level in patients infected with Ascaris lumbricodes. World J. Gastroentrol., 9: 2332-2334.

Lim AK, Nikolic-Paterson DJ, Ma FY. 2009. Role of MKK3-p38 MAPK signalling in the development of type 2 diabetes and renal injury in obese $\mathrm{db} / \mathrm{db}$ mice. Diabetologia, 52: 347-358.

Mossa MM, Bushra, MM, Salih MR, May NY. 2009. Estimation of malondialdehyde as oxidative factor and glutathione as early detections of hypertensive pregnant women. Tikrit Medical Journal, 15: 63-69.

Motala AA, Esterhrizen T, Gouwa E. 2008. Diabetes and other disorders of hyperglycaemia in a South African Community: Prevalence and associated risk factor. Diabetes Care, 31: 17831788.

Motala AA. 2002. Diabetes trends in Africa. Diabetes. Metabolism Research Review, 18: 514-520.

Musa DI, Ibrahim DM, Toriola AL. 2002. Cardiorespiratory fitness and risk factors of CHD in pre-adolescent Nigeria girls. J. Human movement studies, 4: 455-456.

Partec Cyflow Counter (PCC) 2006. Typical steps of particle analysis using Partec cyflow counter. Instrument Operating manual. Partec GmbH OHO-Hann-str 32, 0-48161 Munster, Germany, Pp 58.

Remuzzi G, Schieppati A, Ruggenenti P. 2002. Nephropathy in patients with type 2 diabetes. The New England Journal of Medicine, 346: 1145-1151.

Rowley WR, Bezold C. 2012. Creating public awareness: state 2025 diabetes forecasts. Population Health Management, 15: 12-14.

Sayolah SH, Miret M, Sung J, Varas C, Gause D, Brancati FL. 2001. Post challenge hyperglycemia and mortality in a national sample of US adults. Diabetes Care, 24: 1397-1402.

Stehouwer D. 2004. Endothelial dysfunction in diabetic nephropathy: state of the art and potential significance for non- 
diabetic renal disease. Nephrology Dialysis Transplantation, 19: 778-781.

Su SC, Pei D, Hsieh CH, Hsiao FC, Wu CZ, Hung YJ. 2010. Circulating proinflammatory cytokines and adiponectic in young men with type 2 . diabetes. Acta Diabetologica, 14: 190200.

Wang Y, Harris DC. 2011. Macrophages in renal disease. Journal of the American Society of Nephrology, 22: 21-27.

Wolf G, Ritz E. 2003. Diabetic nephropathy in type 2 diabetes prevention and patient management. Journal of the
American Society of Nephrology, 14: 1396-1405.

World Health Organization. 2003. Expert committee on the diagnosis and classification of diabetes mellitus. Follow up report on the diagnosis of diabetes mellitus. Diabetes Care, 26: 3160-3167.

Yamagishi SI, Fukami K, Ueda S, Okuda S. 2007. Molecular mechanisms of diabetic nephropathy and its therapeutic intervention. Current Drug Targets, 8: 952-959. 